\title{
Opetusmaatilat ja kestävä kehitys
}

Susanna Tauriainen

Opetushallitus, Kumpulantie 3, 00520 Helsinki, susanna.tauriainen@oph.fi

\section{Tiivistelmä}

Yhteiskunnassa tapahtuvien muutosten vuoksi ympäristökysymykset ovat nousseet yhä tärkeämmäksi. Maatalouteen kohdistuu elintarviketuotannon lisäksi yhä lisääntyvässä määrin yhteiskunnan eri tahoilta myös muita odotuksia. Maaseudun odotetaan säilyttävän luonnon monimuotoisuuden, säilyttävän perinteisen maalaismaiseman ja pitämään maaseutu elinvoimaisena. Suomen liityttyä Euroopan Unioniin maatalouden ympäristötukijärjestelmää vuonna 1992 lähdettiin käytännössä toteuttamaan. Kestävän kehityksen huomioiminen ja edistäminen on välttämätön osa maatalouden kilpailukykyä ja imagoa. Viimeisen vuosikymmenen aikana suorat valumat lantaloista on saatu pääsääntöisesti loppumaan. Ravinnekuormitusta vähennetään nyt peltoviljelystä. Kuormituksen muutokset ovat kuitenkin hitaita. Maatalouden ympäristötukijärjestelmän ansiosta ravinteiden käyttömäärät ovat vähentyneet ja peltomaassa ravinnepitoisuudet eivät enää nouse. Fosforin kuormitusriski kasvoi 1990-luvulle asti, mutta nyt kasvu näyttää olevan taittumassa. Eroosion torjunta on vähentänyt fosforin kulkeutumista vesistöön. Typpitase on selvästi vähentynyt viimeisen kymmenen vuoden aikana. Ympäristötuen perinnebiotooppien hoidon erityistuki on hyödyttänyt suurta määrää tavanomaisia, taantuneita ja uhanalaisia eliölajeja.

Suomessa on opetuksessa hyvä kansainvälinen maine perusopetuksessa ja toisen asteen koulutuksessa. Maatalousopetuksen erityispiirteitä toisen asteen koulutuksessa ovat noin kolmekymmentä opetusmaatilaa ja -puutarhaa oppimisympäristöinä. Niitä on kehitetty voimakkaasti maatilatalouden koulutuksen kehittämisstrategiaan perustuen. Erityisenä kehittämisen kohteena on kestävän kehityksen näkökulman korostaminen ja esille tuominen sekä avoimuus. Opetusmaatilojen toiminnot eli eri tuotantoprosessit tuodaan näkyviksi vuoden 2008 aikana internettiin luonnonvara- ja ympäristöalan omaan avoimeen oppimisympäristöön virtuaalikylään. Virtuaalikylää kehitetään tämän jälkeen yhdessä opiskelijoiden kanssa osana heidän oppimisprosessiaan.

Asiasanat: maatalous, opetus, kestävä kehitys, ympäristö, verkkopedagogiikka

\section{Kestävää kehitystä ohjaavat kansainväliset ja kansalliset sopimukset}

Ilmastonmuutosta koskeva yleissopimus (United Nations Framework Convention on Climate Change, UNFCCC) solmittiin YK:n ympäristö- ja kehityskonferenssissa Rio de Janeirossa vuonna 1992. Sopimuksen tarkoituksena oli vakiinnuttaa ilmakehän kasvihuonekaasujen pitoisuus sellaiselle tasolle, joka ei vaaranna ilmakehän tilaa ja toimintaa. Teollisuusmaiden ja siirtymätalouden maiden ryhmän yhteiseksi tavoitteeksi asetettiin ihmisen toiminnasta aiheutuvien kasvihuonekaasupäästöjen tason palauttaminen vuoden 1990 tasolle. Velvoitteita kuitenkin tiukennettiin ja vuonna 1997 ns Kioton pöytäkirjassa määriteltiin teollisuus- ja siirtymätalousmaille maakohtaiset päästövähennys- ja rajoittamisvelvoitteet vuosille 2008-2012. Euroopan unioni sitoutui vähentämään päästöjään 8 \%. Suomen sitoumus on palauttaa päästöt vuoden 1990 tasolle.

Vuonna 2001 laaditun kansallisen ilmastostrategian lähtökohtana on, että Kioton pöytäkirjan tavoite varaudutaan saavuttamaan mahdollisimman kustannustehokkaasti kotimaisin toimin. Näitä ovat muun muassa tutkimuksen ja teknologian kehittäminen, taloudelliset ohjauskeinot, säädökset ja ohjeet sekä tiedotus ja neuvonta. Keskeistä on uusiutuvan energian tuotannon edistäminen sekä energian säästö. 
Kansallista ilmasto-ohjelmaa varten selvitettiin maatalouden kehitysarviossa (MMM 2001:2) toimenpiteitä, jotka ovat tarpeen sisällyttää ohjelmaan Kioton ilmastokokouksessa sovittujen velvoitteiden toteuttamiseksi maatalouden osalta.

Maatalousmaiden hiilidioksidin päästölähteitä ovat kivennäis- ja eloperäisten maiden viljelys ja kalkitus. Suomessa eloperäisinä maina pidetään turvemaita, joita nykyisin on viljelyksessä noin 60000 hehtaaria sekä multamaita, joita on viljelyksessä noin 240000 hehtaaria. Arvioin mukaan maatalouden nykyisistä päästöistä noin kolmannes on peräisin eloperäisiltä viljelymailta. Ilmastonmuutoksen torjuntaa edistäviä toimenpiteitä ovat biomassasta ja biopolttoaineista saatavien uusiutuvien energialähteiden laajempi käyttö sekä non-food -tuotannon edistäminen ja lisääminen.

Ilmastonmuutosta hillitsevien yksittäiset toimenpide-ehdotukset kohdistuvat maataloutta harjoittavien tilojen tuotantotekniikkaan ja viljelymenetelmiin. Näitä ovat muun muassa kotieläinten valkuaisruokinnan muuttaminen, eläinjalostus, tarkennettu lannoitus maatalouden vesistökuormitusten vähentämiseksi sekä lannan käsittelyn, varastoinnin ja levityksen tekniikat. Pellon käytön muutoksilla voidaan myös vaikuttaa kasvihuonepäästöjen vähentämiseen. Esimerkiksi laajamittaista metsän raivausta pelloksi tulisi välttää. Pellon metsitys vähentää kasvihuonepäästöjä erityisesti silloin, kun kyseessä on turve- ja multamaiden metsitys.

Viljelytekniikkaan liittyviä kasvihuonepäästöjä vähentäviä toimenpiteitä ovat maan muokkaamisen vähentäminen, viljelykierrot, kasvipeitteisyyden ylläpitäminen, kasvijätteiden muokkaus maahan, aluskasvien viljelyn suosiminen ja avokesannon välttäminen. Tehokkaasta viljelystä pois jäävää alaa voidaan hoitaa tavalla, joka suosii maan hiilen varastoitumista ja säilyttämistä esimerkiksi laajaperäisenä nurmialana.

Johannesburgin kestävän kehityksen huippukokouksen toimintasuunnitelman uusiutuvia luonnonvaroja ja maaseutua koskevien päätösten pohjalta valmisteltiin Strateginen arvio uusiutuvia luonnonvaroja ja maaseutua koskevista toimista Suomessa (MMM 2004:13) sekä linjauksista Suomen kehitysyhteistyössä, EU:ssa ja kansainvälisesti laajemminkin.

Johannesburgin päätöksen mukaan 1) kestävä maatalous ja maaseutukehitys ovat välttämättömiä ruoantuotannon lisäämiseksi ja turvallisen ruoan osuuden lisäämiseksi ympäristöllisesti kestävällä tavalla. Toimenpide-ehdotuksien mukaan 2) siirretään erityisesti kehitysmaille kestävää maatalouteen liittyvää perustekniikkaa ja tietoa, johon sisältyy luonnonvarojen hallinta, 3) lisätään ruoan saatavuutta ja edullisuutta muun muassa sadonkorjuu- ja ravintoteknologian avulla, 4) parannetaan kestävän maatalouden julkisen sektorin rahoitusta sekä 5) voimistetaan ja parannetaan olemassa olevien aloitteiden koordinointia kestävän maataloustuotannon ja ruokaturvan kehittämiseksi.

Pääosiltaan Johannesburgin päätösten toimeenpanovelvoitteet sisältyvät kattavasti eri kansallisiin ohjelmiin ja strategioihin. Maatalouden osalta Suomessa esitetään lisäksi seuraavia lisätoimenpiteitä Johannesburgin pätötöten saavuttamiseksi. Näiden mukaan toimitaan EU:n yhteisen maatalouden kehittämiseksi niin, että maataloutta pystytään edelleen harjoittamaan koko Suomessa, turvataan toimenpiteet, joilla taataan peltoalan säilyminen sekä viljelykäytössä että viljelykunnossa sekä turvataan maataloustuotanto huoltovarmuuden ylläpitäjänä, kehitetään suomalaisia erikoistuotteita nojautumalla kotimaisten raaka-aineiden laatuun, huolehditaan kotimaisten elintarvikkeiden korkeasta laadusta, edistetään lähiruoan saatavuutta sekä selvitetään monialaisesti lähiruoan asemaa, edullisuutta ja merkitystä osana maatalous-, maaseutu-, alue-, ympäristö- ja kuluttajapolitiikkaa sekä valmistellaan lähiruokaa koskeva strategia. Edelleen tehostetaan maatalouden vesistö- ja muun ympäristökuormituksen vähentämistä ja ylläpidetään maatalouden aikaansaamaa monimuotoisuutta ja maaseutumaisemaa sekä vahvistetaan toimijoiden horisontaalista ja vertikaalista verkostoitumista ja neuvojien toimialakohtaista työtä.

Myös Pohjoismaiden tasolla on tehty yhteinen kestävän kehityksen strateginen linjaus. Pohjoismaiden pääministerit ja itsehallintoalueiden poliittiset johtajat hyväksyivät 1998 julistuksen kestävästä Pohjolasta (ANP 2004:783). Strategiaa on tarkistettu 2004 ja se ulottuu vuosille 2005-2008. 
Strategisissa linjauksissa painottuvat kestävä kuluttaminen, biologinen monimuotoisuuden säilyttäminen, saasteiden rajoittaminen niin, ettei ilmaa, maahan ja veteen kohdistu luonnon kestokyvyn ylittävää saastemäärää.

Maataloutta koskevassa osassa on tavoitteeksi asetettu kestävä maatalous, joka pystyy tuottamaan myös pitkällä aikavälillä terveellisiä ja turvallisia elintarvikkeita ja muita laadukkaita tuotteita heikentämättä luonnonvaraperustaa tai aiheuttamatta haittaa luonnon ekosysteemille. Yhteisinä tavoitteina ja toimenpide-ehdotuksina ehdotetaan muun muassa, että Pohjoismaat lujittavat tutkimukseen ja korkeakoulutukseen liittyvää yhteistyötä. Lisäksi ympäristöyhteistyötä tulee kehittää synergiaetujen sekä ympäristömyönteisyydestä syntyvään lisäarvoon liittyvien konkreettisten parannusten aikaansaamiseksi maataloudessa. Myös innovaatioiden merkitystä maatalouden arvonnousun edistämisessä tulisi korostaa enemmän. Pohjoismaat pyrkivät yhdessä edistämään luonnonmukaista maataloutta sekä luonto- ja kulttuuriarvoja sisältävän maaseutumaiseman monimuotoisuuden vaalimista ja säilyttämistä yhteiskunnan voimavarana pitkällä aikavälillä. Pohjoismaat aikovat turvata eläimille hyvän terveyden ja hyvinvoinnin sekä varmistaa eläinetiikan noudattamisen.

Kestävän kehityksen edistäminen koulutuksessa / Baltic 21E-ohjelmassa (OPM 2002:36) olivat mukana kaikki Itämerta ympäröivät maat. Sopimus perustuu Itämeren maiden opetusministereiden solmimaan sopimukseen edistää koulutuksen keinoin kestävää kehitystä huomioiden kehityksen taloudellinen, sosiaalinen ja ympäristöulottuvuus. Ohjelma täydentää aikaisempaa sopimusta, joka sisältää maatalous-, energia-, kalastus-, metsätalous-, teollisuus-, turismi- ja kuljetussektoreita koskevat kestävän kehityksen toimintaohjelmat.

Luonnonvara-alastrategia (MMM 2001:8) linjaa uusiutuvien luonnonvarojen käyttöä, hoitoa ja suojelua. Strategia huomioi luonnon- ja ympäristönsuojelutavoitteet ja eläinsuojeluun liittyvän tuotantoeläinten eettisen kohtelun. Strategiassa on vision pohjalta määritelty uusiutuvien luonnonvarojen kestävän käytön seitsemän päämäärää. Nämä päämäärät kattavat seuraavat kokonaisuudet: 1) luonnonvarojen eettinen ja vastuullinen hoito ja käyttö, 2) ekosysteemien toimivuus, 3) maaseudun elinvoimaisuus, 4) elinkeinotoiminnan harjoittaminen kannattavasti ja kuluttajalähtöisesti, 5) laajeneva, innovatiivinen ja ekotehokas käyttö, 6) laatu ja turvallisuus sekä 7) tieto ja osaaminen.

Peltobiomassa, liikenteen biopolttoaineet ja biokaasu -jaoston väliraportin (MMM 2004:11) toimenpide-ehdotusten mukaan ruokohelven ja biokaasun tuotantoon liittyvän neuvonnan osuutta tulisi lisätä. Työryhmä esittää uuden bioenergiateknologian käyttöön ottoa eri oppilaitoksissa, jotta bioenergian käyttö ja teknologia tulee tutuksi opiskelijoille. Näissä yksiköissä voisi myös toteuttaa käyttötekniikkaan liittyvää koetoimintaa ja testausta.

Kestävän kulutuksen ja tuotannon toimikunnan (KULTU) kansallinen ohjelman (2005) tavoitteena on materiaalien ja energian käytön tehokkuuden lisääminen tuotteiden elinkaaren kaikissa vaiheissa. Osana ohjelmaa edistetään ympäristökasvatusta sekä ympäristöteknologiaan perustuvaa tuotantoa ja osaamista. Ohjelma on jatkoa Johannesburgissa pidetyn YK:n kestävän kehityksen huippukokouksessa sovittua toimeenpanoa. Ehdotuksiin sisältyy tavoitteita elintarvikkeiden tuotantoon liittyen. Vision mukaan kotimainen ruoantuotanto ja -jalostus säilyvät alueellisen kehityksen, ruoan laadun ja huoltovarmuuden vuoksi. Elintarvikkeet ja ruokapalvelut ovat kestävästi tuotettuja. Suomessa harjoitetaan laajamittaista luomutuotantoa. Maatalous- ja elintarviketuotannon kotimaisia vahvuuksia edistetään tukemalla erityisesti lähi- ja luomuruokaa.

KULTUn tavoitteena on, että maatalouspolitiikassa otetaan huomioon luontaiset tuotantoedellytykset ja painotetaan tuotannon ympäristövaikutuksia. Kestävää maataloutta tulee edelleen vahvistaa maatalouden tukijärjestelmän avulla. Toimikunta ehdottaa, että maataloustuotannossa otetaan nykyistä paremmin huomioon vesien tilan parantaminen ja rehevöitymisen vähentäminen, maatalousympäristön ja -luonnon monimuotoisuuden turvaaminen sekä energiankäytön tehostaminen ja energiaomavaraisuuden nostaminen. Maatalouden ympäristötuen ohjaavuutta tulisi parantaa. Lisäksi 
tavoitteeksi asetettiin luonnonmukaisesti viljellyn peltoalan lisääminen 10 \%:iin vuonna 2010 ja 25 \%:iin vuonna 2025.

Ilmastonmuutoksen kansallisessa sopeutumisstrategiassa (MMM 2005/1) tarkasteltiin laajasti ilmastonmuutoksen tuomia vaikutuksia. Maataloustuotannon osalta ilmaston lämpenemisestä on sekä etuja ja haittoja. Kun ilmasto lämpenee, kasvien tuotantopotentiaali kasvaa, ja viljelyrajat siirtyvät pohjoisemmaksi. Puutarhatuotanto hyötyy lämpenevästä ilmastosta. Kotieläinten ulkolaidunnusta voidaan lisätä. Lisäksi monivuotisten kasvien talvehtiminen helpottunee. Ilmaston lämpenemisen haittapuolia ovat eroosion ja ravinteiden huuhtoutumisriskin lisääntyminen. Ilmaston lämpeneminen tiivistää savimaita. Tämä puolestaan haittaa viljelyä, mikäli routaantuminen vähenee. Ilmansaasteiden (otsoni) ja UV säteilyn yhteisvaikutukset ekosysteemeihin vahvistuvat. Hyönteistuho- ja kasvitautiriski kasvaa. Myös kasvien talvehtiminen voi vaikeutua ja kasteluveden tarve lisääntyä. Äärimmäisten sääilmiöiden lisääntyminen vaikuttaa peltotuotannon sadon määrään ja laatuun.

Maa- ja metsätalousministeriö asetti vuonna 2005 työryhmän valmistelemaan ehdotusta uudeksi maatalouden ympäristötukijärjestelmäksi vuosille 2007-2013. Muistio sisältää arvion maatalousympäristön nykytilasta ja ympäristötuen tavoitteista. Ehdotuksen mukaan uuden ympäristötuen yleistavoitteet säilyvät samansuuntaisina kuin nykyisessäkin ohjelmassa. Näin ollen vesien suojelu on nostettu tärkeimmäksi kohteeksi. Muut toimenpiteet kohdistuvat luonnon monimuotoisuuden ja maiseman säilyttämiseen.

\section{Opetusmaatilojen rooli maatalousopetuksessa}

Opetusmaatilat toimivat ammatillisten oppilaitosten yhteydessä ainutlaatuisena oppimisympäristönä. Siellä nuori opiskelija saa usein ensimmäisen kosketuksen kodin ulkopuoliseen työympäristöön. Nykyään se voi olla myös ensimmäinen kosketus maatilaympäristöön, jos aikaisempaa kokemusta ei ole. Opetusmaatilojen toiminnalla on pitkät perinteet. Opetusmaatiloja on yhteensä reilu kolmekymmentä ympäri Suomea maatalousalan opetuspisteiden läheisyydessä. Opetusmaatilojen tehtävänä on toimia oppimisympäristönä sekä työssäoppimispaikkana ammatillisten oppilaitosten opiskelijoille maatalousalalla. Opetusmaatilojen toiminta on välttämätöntä, jotta opiskelijoille tarjotaan tilat, välineet ja osaamisen malli ammatin kannalta vaadittujen perustaitojen saavuttamiseksi.

Opetusmaatiloilta myös odotetaan paljon. Sen pitäisi olla nykyaikaisen maatilayrityksen keulakuva, jossa on viimeisin tekniikka ja asiantuntevia opettajia. Valitettavasti opetusmaatilan ylläpitäminen on kallista. Niinpä uudistuksia ei aina pystytä tekemään ajan vaatimassa tahdissa. On kuitenkin tärkeää muistaa, että opiskelijan perustaitojen harjaatuminen ja tietopohjan hankkiminen ei ole uusimmasta tekniikasta kiinni. Yli puolet opetusmaatiloista on tällä hetkellä ajanmukaisesti varustettuja. Lisäksi useassa opetuspisteessä uudelleenrakentamista suunnitellaan.

Luonnonvara- ja ympäristöalan koulutuksella on suuri vastuu ympäristön hoitamisesta ja luonnon monimuotoisuuden säilyttämisestä. Opetusmaatilat tarjoavat hyvän yhteisen foorumin sidosryhmille ja muulle koulutukselle esimerkeiksi siitä, miten paljon jo lainsäädäntö asettaa vaatimuksia maatalouden harjoittamiselle. Usein asian vaikuttavuus jää vaille sitä kuuluvaa huomiota. Nämä nykypäivän maaseutuyrittäjän ammattiosaamiseen sisältyvät ympäristöosaaminen halutaan saattaa laajempaan tietoon.

Laadukas koulutuksen järjestäjä panostaa jatkuvaan palautejärjestelmään. Ympäristöasiat on luontevaa sitoa osaksi maatilan laatujärjestelmää. Maatilatalouden koulutuksen strategian toimenpiteiden mukaisesti jokaisella maatalousalan oppilaitoksella tulee olla toimiva ympäristö- ja laatujärjestelmä vuoteen 2010 mennessä. Opetusmaatilojen ja -puutarhojen tulee toimia esimerkkinä kestävän ympäristön huolehtimisesta. Opetusmaatilojen toimintaa on kehitettävä läpinäkyvämpään suuntaan niin, että sen toimintoja voi seurata esimerkiksi reaaliajassa internetin välityksellä. Kaikkien opetusmaatilojen ja - puutarhojen toiminnot tullaan kuvaamaan kestävän kehityksen näkökulmasta. 
Opetusmaatilat löytyvät kehittämistyön jälkeen virtuaalikylästä (www.virtuaalikyla.fi). Ne toimivat esimerkkeinä alan opetuksessa, mutta tarjoavat myös yleiskuvan muille koulutusasteille siitä, miten opetusmaatiloilla ympäristöasiat huomioidaan.

Virtuaalikylä on uudenlainen oppimisympäristö, jonka avulla opiskelijat voidaan tutustuttaa maatilojen ja muiden maaseutuyritysten normaaliin arkeen. Virtuaalikylä on internettiin tuotettu maaseutuympäristö, jota käytetään opetuksen tukena. Virtuaalikylä mahdollistaa eri kouluasteiden ja koulutusalojen välisen yhteistyön. Virtuaalikylän avautuu vapaasti kaikille, joita kiinnostaa käydä tutustumassa oikean maatilan toimintaan. Tietokoneen ääreltä voi seurata niin kevätkylvöjen etenemistä kuin lypsykarjan maitotuotoksien kehittymistä.

\section{Virtuaalikylä avoimuuden ja oppimisen edistäjänä}

Virtuaalikylää on rakennettu kolmessa eri hankkeessa; VirtuaaliAMK:n ESR-osarahoitteisissa sisällöntuotantohankkeessa vuosina 2001-2003 sekä AMK-verkosto -hankkeessa, joka alkoi vuonna 2004 ja jatkuu vuoden 2006 loppuun sekä OPH:n virtuaalikouluhankkeessa 2003 - 2004. Rahoittajina ovat olleet kaikki ammattikorkeakoulut omarahoitusosuuden muodossa sekä Hämeen ammattiinstituutti, Mustiala. Virtuaalikylän teknisestä ideoinnista ja toteutuksesta on vastannut Joutsalainen Dataseed Oy. Kylään voidaan helposti sijoittaa uusia maaseutuyrityksiä tai niiden osia.

Virtuaalikylän tavoitteena on toteuttaa virtuaalinen internetissä toimiva luonnonvara-alan koulutusta palveleva laaja-alainen, moderni virtuaalinen oppimisympäristö, jossa voi tutustua oikean maatilan kaikkiin toimintoihin. Tavoitteena on, että virtuaalikylästä löytyy sekä yritys- että kylätason tietosisältöä, kaupungin ja maaseudun vuorovaikutukseen, laajimmillaan jopa koko yhteiskunnan kuvaamiseen liittyvää havainnollista aineistoa siltä osin kuin se luonnonvara-alan opetuksessa on tarpeen. Virtuaalikylästä mahdollistaa myös kansainvälisen näkökulman. Virtuaalikylää laajennetaan ja kehitetään koko ajan.

Virtuaalikylä soveltuu opetustilanteisiin, jossa on mahdollisuus hyödyntää tietokonetta ja internetiä. Virtuaalikylä on rakennettu niin, että siellä olevia materiaaleja voi käyttää kaikessa luonnonvara-alan opetuksessa. Se antaa mahdollisuuden tutustua toisaalta koko maatilan toimintaan kokonaisuutena, mutta sieltä löytyy myös hyvin yksityiskohtaisia tietoja. Muun muassa jokaisen lehmän sukupuu, terveys ja tuotantotiedot ovat kuvattu sinne tarkasti.

Virtuaalikylää ja sen sisältämiä aineistoja opettaja voi hyödyntää itse valitsemallaan tavalla eri opintojaksojen toteutuksessa. Virtuaalikylää sopii sellaisenaan maaseutuyritysten toimintaan perehdyttävänä orientoivana aineistona. Sitä voi käyttää myös perus- ja syventävissä ammattiopinnoissa, jolloin ratkaiseva osuus on opettajan rakentamissa oppimistehtävissä ja ongelmanasetteluissa. Esimerkkitilojen avulla opiskelijat voivat tehdä lähtötietoihin perustuvia tehtäviä tai vaikkapa rakennettaessa eri tuotantotapojen vertailuun perustuvia tehtäviä. Tehtävät voivat olla hyvin erityyppisiä. Esimerkiksi jokainen voi käydä kokeilemassa, miten hyvin onnistuu kasvattamaan virtuaalivasikkaa. Se löytyy seuraavasta osoitteesta: http://www.dataseed.fi/demo/virtuaalikyla/vasikka/

Vuoden 2007 aikana maaseutuoppilaitosten johtoa, opettajia sekä muuta henkilökuntaa on koulutettu ympäristösertifiointiin tähtäävään toimenpiteisiin. Samanaikaisesti on kehitetty oppilaitoksen opetusmaatilan ja -puutarhan toimintoja, erityisesti ympäristökysymysten kannalta niin, että ne voidaan laittaa internet sivustoille maakunnan maaseutuosaamisen mainosikkunoiksi. Virtuaalikylään tuotetaan aineistoa mm siitä, mitä energiaa opetusmaatiloilla käytetään ja kuinka paljon. Samoin pystytään seuraamaan ylipäätään systemaattisesti tuotantopanosten kulutusta suhteessa tiettyyn aikajaksoon ja tuotettuun tuotokseen. Raportit eri opetusmaatiloilta ovat vertailtavissa ja niitä hyödynnetään opetuksessa. 
Maatilatalouden koulutuksen strategian toimeenpanoon kuuluu myös eri henkilöstöryhmille suunnattava täydennyskoulutus. Lisäksi on päivitetty ja/tai tehty uusia oppikirjoja, joihin on sisällytetty kestävän kehityksen tarkastelu aina kunkin oppiaineen ja/tai opintokokonaisuuden näkökulmasta. Kestävän kehityksen huomioimisesta toisen asteen opetuksessa on ilmestynyt opettajien käyttöön oma teos, sillä kestävä kehitys on osa opiskelijan ammattiosaamisen arviointia. Vuonna 2008 julkistetaan laaja kestävän kehityksen verkkomateriaali ammatillisten opettajien opetuksen tueksi.

\section{Kirjallisuus}

MMM 2001. Maatalouden kehitysarvio kansallista ilmasto-ohjelmaa varten. Työryhmämuistio, maa- ja metsätalousministeriö 2001:2.

MMM 2001 Luonnonvara-alastrategia. MMM 2001:8.

MMM 2004. Johannesburgin kestävän kehityksen huippukokousten päätökset. Strateginen arvio uusiutuvia luonnonvaroja ja maaseutua koskevista toimista. Maa- ja metsätalousministeriön julkaisuja, 2004:13.

MMM 2004. Peltobiomassa, liikenteen biopolttoaineet ja biokaasu -jaoston väliraportti, MMM 2004:11

MMM 2005. Ilmastonmuutoksen kansallinen sopeutumisstrategia 2005. Maa- ja metsätalousministeriö 2005:1.

OPM. 2006. Kestävän kehityksen edistäminen koulutuksessa; Baltic 21E -ohjelman toimeenpano sekä kansallinen strategia YK:n kestävää kehitystä edistävän koulutuksen vuosikymmentä (2005-2014) varten. Opetusministeriön työryhmämuistioita ja selvityksiä 2006:6.

YM 2005. Kestävän kulutuksen ja tuotannon toimikunnan (KULTU) ehdotus kansalliseksi ohjelmaksi 2005. Vähemmästä enemmän ja paremmin. 